\title{
Spectroscopic and Gas Chromatographic Studies of Pigments and Binders in Gdańsk Paintings of the 17th Century
}

\author{
Justyna Olszewska-Świetlik, ${ }^{1}$ Bożena Szmelter-Fausek, ${ }^{1}$ \\ Ewa Pięta, ${ }^{2}$ and Edyta Proniewicz ${ }^{2,3}$ \\ ${ }^{1}$ Department of Painting Technologies and Techniques, Nicolaus Copernicus University in Toruń, Ulica Sienkiewicza 30/32, \\ 87-100 Toruń, Poland \\ ${ }^{2}$ Faculty of Chemistry, Jagiellonian University, Ulica Ingardena 3, 30-060 Kraków, Poland \\ ${ }^{3}$ Faculty of Foundry Engineering, AGH University of Science and Technology, Ulica Reymonta 23, 30-059 Krakow, Poland \\ Correspondence should be addressed to Justyna Olszewska-Świetlik; justyna.olszewska-swietlik@umk.pl
}

Received 5 September 2013; Accepted 30 October 2013

Academic Editor: Yizhuang Xu

Copyright (C) 2013 Justyna Olszewska-Świetlik et al. This is an open access article distributed under the Creative Commons Attribution License, which permits unrestricted use, distribution, and reproduction in any medium, provided the original work is properly cited.

\begin{abstract}
This work presents spectroscopic (optical microscopy, OM; micro-Raman, Raman; and Fourier-transform adsorption infrared, FT-IR) and gas chromatographic studies of two famous panel paintings from the Gdańsk artists of the 17th century Golden Age, "Servilius Appius" by Isaac van den Blocke and "Allegory of Wealth" probably by Anton Möller. Application of the aforementioned methods allowed us to identify pigments and binders used in the panel paintings. In particular, it was determined that the yellow pigment used by both artists is lead-tin yellow type I $\left(2 \mathrm{PbO} \cdot \mathrm{SnO}_{2}\right)$, the white pigment is lead (II) carbonate hydroxide $\left(2 \mathrm{PbCO}_{3} \cdot \mathrm{Pb}(\mathrm{OH})_{2}\right)$, and the ground layer material consist of chalk $\left(\mathrm{CaCO}_{3}\right)$. The analysis showed also that in the case of "Allegory of Wealth," the red layer consists not only of cinnabar (HgS) but also of lead-tin yellow type I.
\end{abstract}

\section{Introduction}

Several documentary sources from the 17th century give recipes on how to paint, prepare grounds, and use colors for particular parts of the painting [1-4]. For example, De Mayerne pronounced that the quality of the materials used is essential not only for the ground layer but also for the paint layer. He recommended putting two different ground layers on the support. The first ground layer consisted of a very thin chalk-glue $\left[\mathrm{CaCO}_{3}-\right.$ a white pigment used as a painting ground since antiquity [5]] that he polished. Then, he applied a second layer of lead (II) carbonate hydroxide $\left[\left(\mathrm{PbCO}_{3}\right)_{2} \cdot \mathrm{Pb}\right.$ $(\mathrm{OH})_{2}-$ a synthetic pigment produced since antiquity using an acidic organic compound on metallic lead $[6,7]$ with umber $\left[\mathrm{Fe}_{2} \mathrm{O}_{3} \cdot \mathrm{H}_{2} \mathrm{O}+\mathrm{MgO}+\mathrm{Al}_{2} \mathrm{O}_{3}\right][1]$. Lead (II) carbonate hydroxide, lead-tin yellow [light (type 1) $-\mathrm{Pb}_{2} \mathrm{SnO}_{4}$ and dark (type II)- $\left.\mathrm{Pb}(\mathrm{Sn}, \mathrm{Si}) \mathrm{O}_{3}\right]$, yellow ochre $\left[\mathrm{Fe}_{2} \mathrm{O}_{3} \cdot \mathrm{H}_{2} \mathrm{O}\right]$, vermilion [HgS, a synthetic equivalent of cinnabar [8]], red lead [minimum, $\mathrm{Pb}_{3} \mathrm{O}_{4}$ ], carmine (organic red-carminic acid), iron oxide red $\left[\mathrm{Fe}_{2} \mathrm{O}_{3}\right]$, natural azurite $\left[\mathrm{Cu}_{3}\left(\mathrm{CO}_{3}\right)_{2}(\mathrm{OH})_{2}\right]$, smalte $\left[\mathrm{CoO} \cdot n \mathrm{~K}_{2} \mathrm{SiO}_{3}\right]$, natural malachite $\left[\mathrm{Cu}_{2} \mathrm{CO}_{3}(\mathrm{OH})_{2}\right]$, copper green $\left[\mathrm{Cu}\left(\mathrm{CH}_{3} \mathrm{COO}\right)_{2}\right]$, and charcoal were the most common pigments used in the 17th century [8]. Massicot $[\mathrm{PbO}]$, schüttgelb (yellow lake pigment-organic pigments from many different sources), and orpiment $\left[\mathrm{As}_{2} \mathrm{~S}_{3}\right]$ were also mentioned in the documentary sources from this period [14]. However, the later literature noted that lead-tin yellow was incorrectly identified as massicot $[9,10]$. For example, De Mayerne suggested using massicot (in fact lead-tin yellow), yellow ochre, and schüttgelb to paint lighted and shaded surfaces, as well as transition from light to shade [1-4].

Despite progress in the field of instrumental analysis, identification of some of the pigments present in the painting layers, especially lead-tin yellow, is not always a simple task. Depending on the method of preparation, two types of leadtin yellow can be obtained (type I and type II).

Recipes for lead-tin yellow are given in the Bolognese Paper Segreti per colori from the XVth century: "272. To 
make yellow glass for paternosters or beads. Take of lead $1 \mathrm{lb}$., of tin $2 \mathrm{lbs}$., melt and calcine them, and make glass for paternosters." and "273. To make giallolino for painting. Take $2 \mathrm{lbs}$. of this calcined lead and tin, that is $2 \mathrm{lbs}$. of this glass for paternosters, $2.5 \mathrm{lbs}$. of minimum, and $0.5 \mathrm{lb}$. of sand from Val d'Arno pounded very fine; put it into a furnace and let it fine itself and the color will be perfect" [11]. According to a different recipe, lead-tin yellow was obtained by heating approximately 3 parts of the oxide, lead dioxide, or most often minium with 1 part of tin oxide [10, 12-14].

Lead-tin yellow type I occurs more frequently in art than does lead-tin yellow type II. This pigment was widely applied from antiquity to the first half of the 18th century [15]. Its early use was characteristic in Northern Europe. However, from the second half of the XVth century, it was identified in paintings from several European schools. For example, lead-tin yellow type I was found in the paintings of the Netherlandish artists Master of the Saint Bartholomew (1475-1510) and Gerard David (1460-1523), the Flemish artist Anthony van Dyck (1599-1641), and the Dutch artists Hendrick ter Brugghen (1588-1629) and Meindert Hobbema (1638-1709), whose works are in the National Gallery in London [7]. In works from the Polish collections, lead-tin yellow type I, in trace amounts, was identified in the Dutch triptych "The Last Judgement" (1473) by Hans Memling (14351494) (the National Museum in Gdańsk) [16].

Lead-tin yellow type II was obtained from lead glass, according to the procedure given in the Bolognese Paper $[10,12-14]$. This type of yellow was used more often in the southern schools of painting, and the earliest example was identified in the paintings of Giotto di Bondone (1266-1377) and Jacopo di Cione (1325-1399) [7]. In the second half of the $\mathrm{XVth}$ century in Italy, lead-tin yellow type II was replaced by lead-tin yellow type I [7]. Examples include works by Moretto da Brescia (1498-1555) and Paolo Veronese (1528-1588) from the collections of the National Gallery in London, in which lead-tin yellow type I was identified by X-Ray Diffraction analysis [16].

During the 16th and 17th centuries, Gdańsk was a wealthy seaport and merchant city. Many artists, including immigrants from the Netherlands, lived in Gdańsk and composed their works of art that influenced the native Gdańsk artists. One of the families that settled in Gdańsk was the van den Blocke family from Mechelen (Flanders). They took up construction, ornamental masonry, and painting. Isaac van den Blocke was a painter and gained a reputation as a splendid artist for the Main Town Hall in Gdańsk (1606-1609) [17].

The second outstanding Gdańsk artist is Anton Möller, who arrived in Gdańsk from Królewiec. Möller's art was influenced by Netherlandish and German painters. His famous work is "The Last Judgement" (1602-1603) from Arthus Court in Gdańsk.

Both artists are best known for Biblical themes and allegorical compositions that are often compared to the art of Flanders and the Netherlands.

The main aim of the analysis presented in this work was to supplement the data on the type of lead-tin yellow pigment used in the Gdańsk paintings in the first half of the XVIIth century, using the two example paintings "Servilius

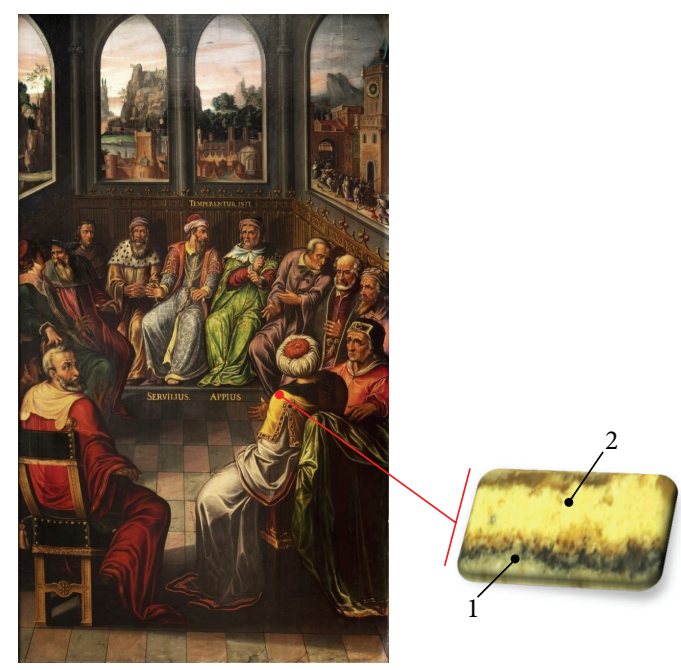

Figure 1: "Servilius Appius" (1608-1609) by Isaac van den Blocke and a cross-section of sample (SA): SA.1-white ground layer/underpainting and SA.2-yellow painting layer.

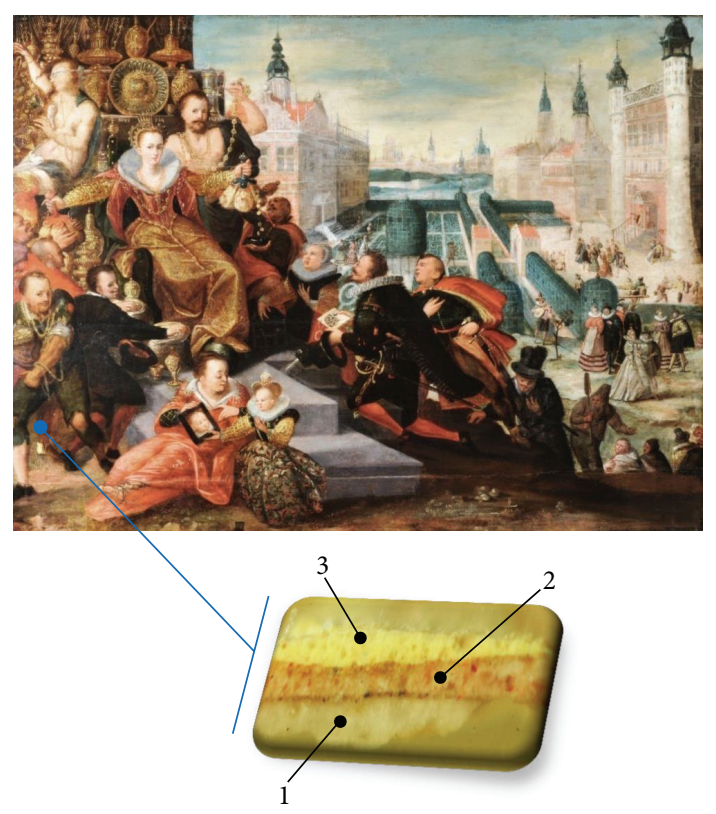

Figure 2: "Allegory of Wealth" (c. 1600) by Anton Möller and a cross-section of sample (AW): AW.1-white ground layer/underpainting, AW.2-red painting layer, and AW.3-yellow painting layer.

Appius" by Isaac van den Blocke (Figure 1) and "Allegory of Wealth," most likely by Anton Möller (Figure 2). This work is important because the examination of the type of leadtin yellow in a greater number of paintings will contribute to a full view of the technologies and techniques that were used and the types of materials in the paintings in different regions of Europe. The second goal of the research was to gain analytical information on the inorganic and organic materials used for grounds, painting layers, and varnishes in both paintings to better understand and characterize their 
painting technique. It was important to identify the pigments, how complex the binding media mixtures used for the layers were, and if the paintings show any characteristic features related to certain schools of painting. The obtained data were also important to better plan the sustainable conservation of the paintings. The present research is the first spectroscopic investigation of the Gdańsk 17th century paintings. Until now, the Gdańsk 17th century paintings have been studied only by art historians.

"Servilius Appius" (1608-1609) was painted for the Red Chamber in the Main Town Hall in Gdańsk (now The Gdańsk History Museum). Isaac van den Blocke placed more emphasis on the political and administrative content of this painting than on its artistic value. The theme of the painting was directed to the city council and warned against conflicts. It emphasizes cooperation as an important virtue for governance [18]. Blocke mainly used yellow colors in particular parts of garments, that is, collars and clothing finishing.

"Allegory of Wealth" (1600) is part of an allegorical cycle, along with the two paintings known as "The Model of the World and the Gdańsk Citizens" and "Allegory of Pride." The paintings point out vices of the citizens of Gdańsk. The author mainly painted with yellow color in detail such as shoes or ornamentals on the textiles of robes.

A multidisciplinary approach was undertaken to accomplish these goals. Optical microscopy (OM), gas chromatography (GC), Fourier-transform absorption infrared (FT-IR), and micro-Raman (Raman) analysis answered questions regarding the type of lead-tin yellow or the particular pigments and binders used in paintings of this type.

\section{Materials and Methods}

2.1. Samples. Two samples were taken from yellow parts of the paintings: the yellow vest from "Servilius Appius" by Isaac van den Blocke (SA) and the yellow shoe from "Allegory of Wealth" by Anton Möller (AW). The cross-sections were prepared by setting the samples in resin and polishing the sample.

2.2. Optical Microscopy Measurements. OM measurements were carried out using a Nikon Optiphot-2 (NIKON INC., USA) conventional reflected light microscope.

2.3. Micro-Raman Measurements. The micro-Raman spectra of selected layers were recorded using an InVia spectrometer (Renishaw, England). This spectrometer was equipped with a diode laser emitting at $785.0 \mathrm{~nm}$ and a CCD detector. The laser power at the output was set at $30 \mathrm{~mW}$. All spectra were acquired with a spectral resolution of $4 \mathrm{~cm}^{-1}$ in the 100 to $3200 \mathrm{~cm}^{-1}$ spectral range. Depending upon the signal to noise ratio $(\mathrm{S} / \mathrm{N}), 4$ to 16 scans were collected.

\subsection{Fourier-Transform Absorption Infrared Measurements.}

The FT-IR spectra of SA and AW samples (ground, underpainting, painting layer, and varnish) were obtained with a Bruker Optics Alpha ATR FTIR spectrometer in the spectral range of 4000-500 $\mathrm{cm}^{-1}$ (Jadwiga W. Łukaszewicz, Wiesława Topolska, Department for Conservation and Restoration of Architectonic Elements and Details, The Institute for the Study, Restoration and Conservation of Cultural Heritage, Nicolaus Copernicus University in Toruń, Poland).

2.5. Gas Chromatography Measurements. Samples were decomposed to separate binders on the column. First, a $2 \mathrm{M}$ methanolic $\mathrm{KOH}$ solution was used, followed by methylation with methyl chloroformate (MCF) and the hexane extraction of methyl esters of saturated fatty acids and dicarboxylic acids such as azelaic acid.

For these measurements, a Hewlett Packard 6890 Chromatograph equipped with a $30 \mathrm{~m}$ HP5 capillary column and flame ionization detector FID was used. The separation was performed in a programmable temperature furnace (Grzegorz Jaworski, Department of Painting Technologies and Techniques, The Institute for the Study, Restoration and Conservation of Cultural Heritage, Nicolaus Copernicus University in Toruń, Poland).

The obtained chromatograms were interpreted qualitatively by comparing the chromatograms of the reference binder, such as linseed oil and casein. From the chromatogram integration results, the ratios between acids were determined, that is, $\mathrm{Az} / \mathrm{Pa}, \mathrm{Pa} / \mathrm{St}$, and $\mathrm{Pa} / \mathrm{My}$, where $\mathrm{Az}, \mathrm{Pa}$, St, and My denote azelaic, palmitic, stearic, and myristic acids, respectively. Unfortunately, due to the small amount of sample taken from the painting "Allegory of Wealth," it was not possible to measure the binding media of the selected layers in the AW sample. Consequently, the measurements were performed on a sample that included all layers.

Before the GC analysis was performed, a complementary microchemical saponification test was performed with the samples to verify the presence of oil in the particular layers.

\section{Results and Discussion}

3.1. Vibrational Analysis. Analysis of a cross-section of SA (inset in Figure 1) and AW (inset in Figure 2) samples by optical microscopy and micro-Raman spectroscopy (Figures 3 and 4 ) revealed that the samples are multilayered and have two and three layers, respectively. The SA sample consisted of the following layers: SA.1-white ground layer/underpainting and SA.2-yellow painting layer (see Table 1); in contrast, the AW sample displayed the following layers: AW.1-white ground layer/underpainting, AW.2-red painting layer, and AW.3-yellow painting layer (see Table 1). Each Raman spectrum from the individual cross-section shows unique bands due to particular pigments. The spectral analysis of these bands was based on the spectral databases of pigments [19-40].

Raman analysis of the SA.1 layer (Figure 3) identified a mixture of pigments in this layer that yield a spectrum with strong bands from chalk (at 1087 and $278 \mathrm{~cm}^{-1}$ ) and lead (II) carbonate hydroxide (at $1054 \mathrm{~cm}^{-1}$ ). The presence of lead (II) carbonate hydroxide in the SA.1 layer is a consequence of mixing the ground layer with the very thin layer of underpainting. The Raman spectrum of the yellow painting 
TABLE 1: Stratigraphy and results of the measurements of pigments and binders of a cross-section of the SA and AW samples.

\begin{tabular}{|c|c|c|c|c|}
\hline \multirow{2}{*}{ No. } & \multirow{2}{*}{ Layer } & \multicolumn{3}{|c|}{ Detected pigments and binders } \\
\hline & & Micro-Raman & FT-IR & GC \\
\hline \multicolumn{5}{|c|}{ SA } \\
\hline 2 & $\begin{array}{l}\text { Yellow } \\
\text { painting } \\
\text { layer }\end{array}$ & $\begin{array}{c}\text { Lead-tin } \\
\text { yellow type I } \\
\left(2 \mathrm{PbO} \cdot \mathrm{SnO}_{2}\right)\end{array}$ & $\begin{array}{l}\text { Oil, } \\
\text { protein, } \\
\text { carbonates }\end{array}$ & $\begin{array}{l}\text { Linseed } \\
\text { oil }\end{array}$ \\
\hline 1 & $\begin{array}{l}\text { white ground } \\
\text { layer/ } \\
\text { underpainting }\end{array}$ & $\begin{array}{c}\text { chalk }\left(\mathrm{CaCO}_{3}\right), \\
\text { lead }(\mathrm{II}) \\
\text { carbonate } \\
\text { hydroxide } \\
\left(2 \mathrm{PbCO}_{3} \cdot \mathrm{Pb}(\mathrm{OH})_{2}\right)\end{array}$ & & $\begin{array}{l}\text { Linseed } \\
\text { oil, } \\
\text { casein }\end{array}$ \\
\hline \multicolumn{5}{|c|}{ AW } \\
\hline 3 & $\begin{array}{l}\text { Yellow } \\
\text { painting } \\
\text { layer }\end{array}$ & $\begin{array}{c}\text { Lead-tin } \\
\text { yellow type I } \\
\left(2 \mathrm{PbO} \cdot \mathrm{SnO}_{2}\right)\end{array}$ & Casein & $\begin{array}{l}\text { Linseed } \\
\text { oil, } \\
\text { casein }\end{array}$ \\
\hline 2 & $\begin{array}{l}\text { Red painting } \\
\text { layer }\end{array}$ & $\begin{array}{l}\text { Cinnabar } \\
(\mathrm{HgS})\end{array}$ & & \\
\hline 1 & $\begin{array}{l}\text { White ground } \\
\text { layer/ } \\
\text { underpainting }\end{array}$ & $\begin{array}{c}\text { Chalk }\left(\mathrm{CaCO}_{3}\right) \\
\text { lead }(\mathrm{II}) \text { carbonate } \\
\text { hydroxide } \\
\left(2 \mathrm{PbCO}_{3} \cdot \mathrm{Pb}(\mathrm{OH})_{2}\right)\end{array}$ & $\begin{array}{l}\text { Casein, } \\
\text { gluten } \\
\text { glue, } \\
\text { carbonates }\end{array}$ & \\
\hline
\end{tabular}

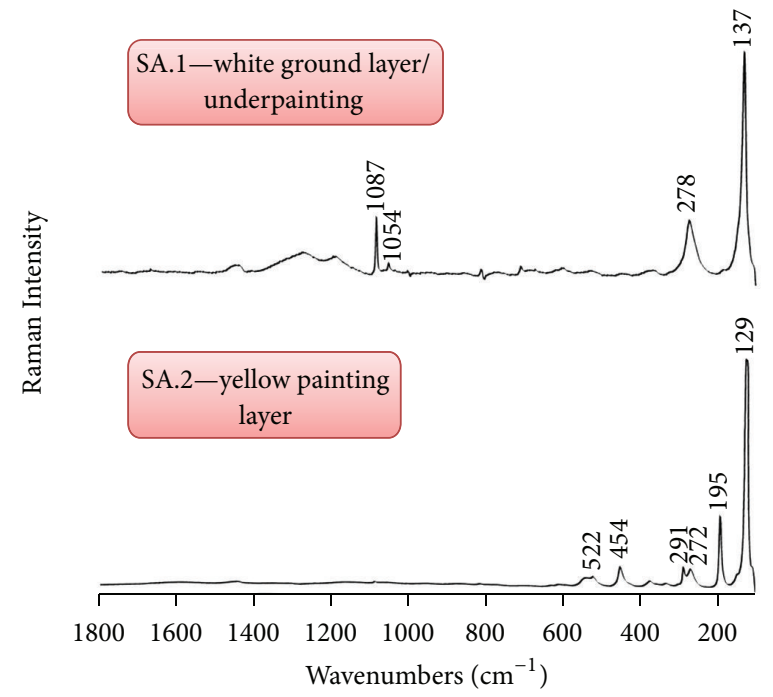

FIgURE 3: Micro-Raman spectra of the cross-section layers of "Servilius Appius" (SA).

layer (Figure 3, SA.2 layer) exhibited a prominent 129, spectral feature, and less intense bands at 195, 272, 291, 454, and $522 \mathrm{~cm}^{-1}$. All of these bands were attributed to lead-tin yellow type I.

The Raman spectrum of the AW.1 layer (Figure 4), similar to the Raman spectrum of the SA.1 layer, is characterized by bands due to the mixture of pigments, such as chalk (at $1088 \mathrm{~cm}^{-1}$ ), lead (II) carbonate hydroxide (at $1052 \mathrm{~cm}^{-1}$ ), and red pigment cinnabar (vermilion, at 252, 282, and $342 \mathrm{~cm}^{-1}$ ). Due to the historical context of the art, bands attributed to cinnabar should not be observed in the AW.1 layer. These

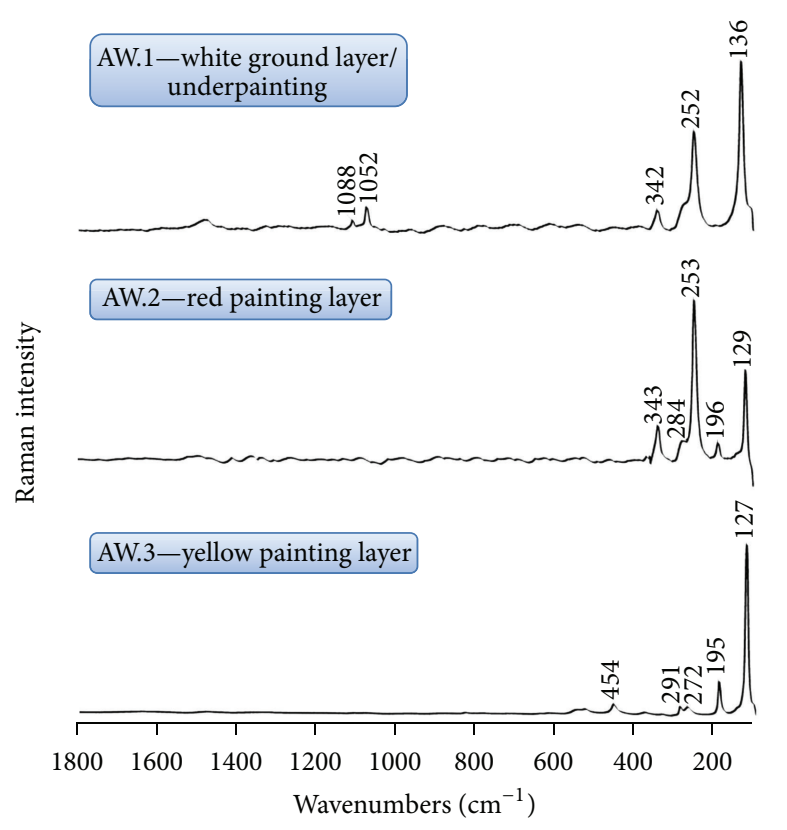

Figure 4: Micro-Raman spectra of the cross-section layers of "Allegory of Wealth" (AW).

results are most likely due to contamination of the sample during embedding in the resin block or displacement of some grains of these pigments from the previous painting layer. The OM and microchemical analyses revealed chalk, charcoal, and lead white in the AW.1 layer. The red painting layer (Figure 4, AW.2 layer) also contains vermilion, as is evident from the presence of the same spectral features as mentioned in the previous cases (layer AW.1). Similar to the Raman spectrum of the SA.2 layer, the AW.3 layer spectrum exhibited bands that corresponded to lead-tin yellow type I (at 127, 195, 272, 291, 454, and $524 \mathrm{~cm}^{-1}$ ).

It should also be noted that both SA.1 and AW.1 spectra contain Raman band at $\sim 137 \mathrm{~cm}^{-1}$ which could not be uniquely assigned to any of pigments. This is due to the fact that there are no additional observed spectral features. Consequently, we could only suppose that this Raman signal arising from the lead tin yellow type I or II.

The identification of varnishes and binding media is one of the most complicated issues for scientists and art conservators. The chemical composition of these materials should be analyzed using spectroscopic and chromatographic techniques such as FT-IR and GC. Figure 5 presents the FT-IR spectra of the sample from the investigated panel paintings, whereas Figure 6 shows their GC chromatograms. The binding media identified in the SA and AW samples based on the FT-IR spectra are linseed oil and protein $[20,23]$. Hence, the observed fatty acids and ester bands in the FTIR spectra may be explained by the use of drying oils in the preparation of the binder. Briefly, in the IR spectra of the SA and AW samples (Figure 5), the $3349 \mathrm{~cm}^{-1}$ band due to the $\mathrm{O}-\mathrm{H}$ bond stretch reveals the presence of the alcoholic groups in the analyzed samples. The 2926 and $2855 \mathrm{~cm}^{-1}$ spectral features correspond to the $\mathrm{C}-\mathrm{H}$ bond 


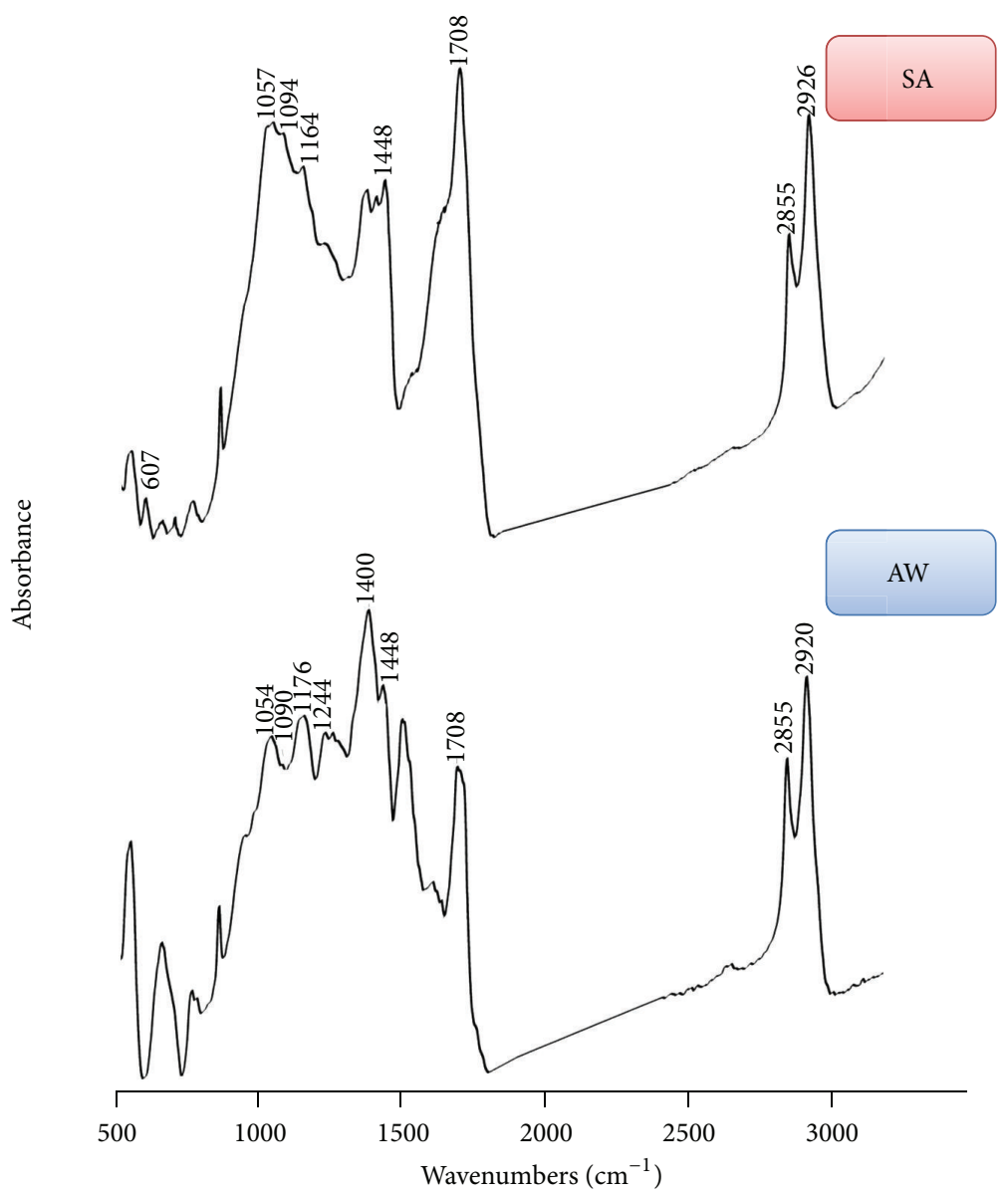

FIGURE 5: FT-IR spectra of sample taken from "Servilius Appius" (SA) and "Allegory of Wealth" (AW).

stretches of the hydrocarbon chains (fatty acids and proteins). The broad intense band with a maximum at $1708 \mathrm{~cm}^{-1}$ and a shoulder at $1658 \mathrm{~cm}^{-1}$ is due to the stretching vibrations of the $\mathrm{C}=\mathrm{O}$ groups of resin acids and the $\mathrm{C}=\mathrm{CH}_{2}$ olefin groups, respectively. Oils and proteins are represented by the characteristic $1448 \mathrm{~cm}^{-1}$ band (deformations of $\mathrm{C}-\mathrm{H}$ in $-\mathrm{CH}_{2}-$ and $-\mathrm{CH}_{3}$ groups), whereas the 878 and $674 \mathrm{~cm}^{-1}$ Raman signals are only assignable to linseed oil. The 1245 , $\sim 1170$, and $\sim 1090 \mathrm{~cm}^{-1}$ spectral features suggest the presence of an ester group. The protein media as an animal glue also shows characteristic protein vibrations, such as the amide I $\left(1658 \mathrm{~cm}^{-1}\right)$ and amide II $\left(1549 \mathrm{~cm}^{-1}\right)$ bands and the aromatic amino acids ring modes $\left(1514,1605 \mathrm{~cm}^{-1}\right)$. In the fingerprint spectral region, the $1448,1378,1164,1094$, and $1057 \mathrm{~cm}^{-1}$ bands may indicate the presence of a triterpenoid resin of dammar. In addition, chalk exhibits typical calcium carbonate bands such as the antisymmetric stretching vibration of $\mathrm{CO}_{3}^{-2}\left(1416\right.$ and $\left.710 \mathrm{~cm}^{-1}\right)$. The presence of the carbonate bands suggests the existence of calcium carbonate bound with calcite in the ground layer and lead (II) carbonate hydroxide in the painting layer and the underpainting.

The type of binding medium used in the investigated panel paintings was also determined using gas chromatography. The chromatograms of the SA (Figure 6, top trace) and
AW (Figure 6, bottom trace) samples indicate the following acids: palmitic $-\mathrm{Pa}$, stearic $-\mathrm{St}$, myristic $-\mathrm{My}$, and azelaic$\mathrm{Az}$. From the results of the integration of the chromatograms, the ratios between the acids can be determined $(\mathrm{Pa} / \mathrm{St}, \mathrm{Az} / \mathrm{Pa}$, $\mathrm{Pa} / \mathrm{My}, \mathrm{Pa}$-palmitic, St-stearic, Az-azelaic, and $\mathrm{My}-$ myristic). The ratios of the painting layer to the SA sample are assignable to linseed oil: $\mathrm{Pa} / \mathrm{St}=1,92, \mathrm{Az} / \mathrm{Pa}=0,26$, and $\mathrm{Pa} / \mathrm{My}$ $=10,37$. The presence of this binder was confirmed by GC and FTIR analysis and the microchemical test. The saponification test also confirmed the presence of oil.

For the ground layer with underpainting, the ratios were $\mathrm{Pa} / \mathrm{St}=2,28, \mathrm{Az} / \mathrm{Pa}=0,19$, and $\mathrm{Pa} / \mathrm{My}=5,64$, which suggests that the binder composition is most likely casein and linseed oil. This result was also confirmed by FT-IR analysis. The GC analysis of the painting layers with the ground of the AW sample assigned the following ratios: $\mathrm{Pa} / \mathrm{St}=$ $4,10, \mathrm{~Pa} / \mathrm{My}=3,92$, and $\mathrm{Az} / \mathrm{Pa}=0,46$, indicating that the binder composition is most likely linseed oil and casein. The microchemical test of saponification of the sample confirmed the presence of oil in the painting layer and underpainting. The FT-IR analysis also confirmed the analyzed binders.

The GC chromatogram of the SA sample (Figure 6, top trace) confirmed the results of the FT-IR analysis (Figure 5, top trace) and revealed linseed oil in the painting layer with underpainting and casein and linseed oil in the ground layer. 

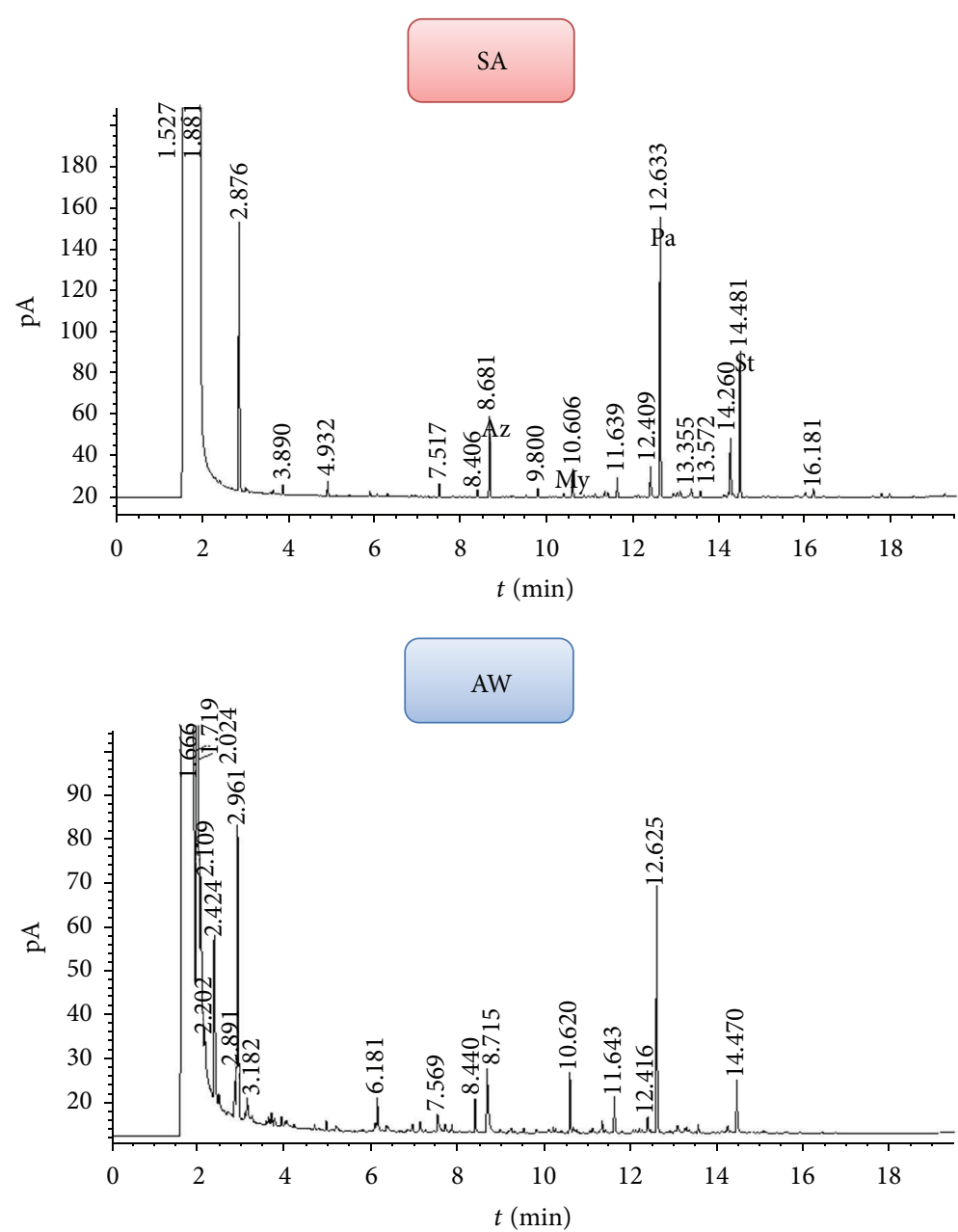

Figure 6: GC chromatogram of "Servilius Appius" (SA) (the integration of the peaks calculated ratios of acids: $\mathrm{Pa} / \mathrm{St}=1,92 ; \mathrm{Az} / \mathrm{Pa}=0,26$; $\mathrm{Pa} / \mathrm{My}=10,37 ; \mathrm{Pa}$ - palmitic acid, St—stearic acid, Az-azelaic acid, and My—myristic acid) and "Allegory of Wealth" (AW) (the integration of the peaks calculated ratios of acids: $\mathrm{Pa} / \mathrm{St}=4,10 ; \mathrm{Pa} / \mathrm{My}=3,92 ; \mathrm{Az} / \mathrm{Pa}=0,38$ ).

The presence of casein and linseed oil was also found in the AW sample (Figure 6, bottom trace), which was confirmed by FT-IR analysis (Figure 5, bottom trace).

\section{Conclusions}

The analyzed paint samples originated from the panel paintings "Servilius Appius" and "Allegory of Wealth." An interdisciplinary approach was used for the investigation of these samples to obtain information about their complex structure and to gain knowledge of the traditional painting techniques and the related technological sources. The OM, micro-Raman, FT-IR, and GC analytical techniques, which characterize all of the usual classes of inorganic pigments and organic binding media from the same microsample were used. The analysis of the binder was necessary to characterize the painting and plan its consolidation.

The performed analysis identified differences between the techniques used. For example, chalk, lead (II) carbonate hydroxide, and lead-tin yellow type I were used in "Servilius
Appius," whereas chalk, lead (II) carbonate hydroxide, leadtin yellow I, and cinnabar (vermilion) were used in "Allegory of Wealth." Blocke painted with oil colors on a white ground that contained chalk and casein and on an underpainting of lead (II) carbonate hydroxide and linseed oil. He used lead-tin yellow type I as a yellow pigment. Möller painted with oil colors on a white chalk-glue-casein ground and an underpainting of lead (II) carbonate hydroxide was then applied. The yellow layer containing lead-tin yellow type I was applied to a red layer of cinnabar (vermilion).

FTIR and GC identified the composition of the binding media. The results were completed by micro-Raman analysis.

The obtained results have been compared with the FTIR data (Figure 5). Due to the small amount of sample, it was not possible to obtain FT-IR spectra from each layer. The combination of RS and FT-IR spectroscopy proved to be complementary in the identification of pigments.

The vibrational analysis of the two panel paintings shows that artists of this period were familiar with using pigments such as lead-tin yellow type I or lead (II) carbonate hydroxide and the same ground layer material chalk. These similarities 
suggest that both of these paintings were created under the influence of the same school or culture.

\section{Conflict of Interests}

The authors declare that there is no conflict of interests regarding the publication of the paper.

\section{Acknowledgment}

This work was supported by the Polish National Science Center of the Ministry of Science and Higher Education (Grant no. N N204 370340 to J. O.-Ś.).

\section{References}

[1] T. T. de Mayerne, "Pictoria, sculptoria, tinctoria et quae subalternarum atrium spectantia," in Quellen für Maltechnik während der Renaissance und deren Folgezeit (XVI.XVIII. Jahrhundert) in Italien, Spanien, den Niederlanden, Deutschland, Frankreich und England, nebst dem de Mayerne Manuskript, E. Berger, Ed., p. 98, Callwey, München, Germany, 1901.

[2] C. van Mander and H. Floerke, Das Leben der niederländischen und deutschen Maler, vol. 2, George Müller, München, Germany, 1906.

[3] C. van Mander, Het Schilder-Boeck, Martinus Nijhoff Publishers, The Hague, The Netherlands, 1916.

[4] M. Roznerska, Paintings Techniques of "Small Netherlands Masters" of XVII Century, Nicolaus Copernicus University, Toruń, Poland, 1991.

[5] I. M. Bell, R. J. H. Clark, P. J. Gibbs, and Christopher Ingold Laboratories, Raman Spectroscopic Library of Natural and Synthetic Pigments, University College London, Department of Chemistry, 2010, http://www.chem.ucl.ac.uk/ resources/raman/index.html.

[6] T. D. Chaplin, R. J. H. Clark, A. McKay, and S. Pugh, "Raman spectroscopic analysis of selected astronomical and cartographic folios from the early 13th century Islamic 'Book of Curiosities of the Sciences and Marvels for the Eyes'”, Journal of Raman Spectroscopy, vol. 37, no. 8, pp. 865-877, 2006.

[7] N. Eastaugh, V. Walsh, T. D. Chaplin, and R. Siddall, The Pigment Compendium: A Dictionary of Historical Pigments, Elsevier Science, Oxford, UK, 2004.

[8] J. Olszewska-Świetlik, Painting Technology and Technique of Selected Modern Epitaphs from the St. Mary's Church in Gdan'sk, Nicolaus Copernicus University, Toruń, Poland, 2009.

[9] R. Jacobi, "Über den in der Malerei verwendeten gelben Farbstoff der alten Meister," Angewandte Chemie, vol. 54, pp. 2829, 1941.

[10] H. Kühn, "Lead-tin-yellow," Studies in Conservation, vol. 13, pp. 7-33, 1968.

[11] M. Merrifield, Original Treatises on the Arts of Painting, vol. 2, Dover, New York, NY, USA, 1967.

[12] Z. Brochwicz and J. Rauchfleisz, Application of X-Ray Spectroscopy to Identification of Inorganic Pigments, Library of Museology and Preservation of Monuments, vol. 34, Warsaw, Poland, 1973.

[13] P. Rudniewski, Pigments and Their Identification, vol. 13, Academy of Fine Arts, Warsaw, Poland, 1994.
[14] Z. Kaszowska, Advantages and Limitations of Analytical Techniques Used in Technological Studies of Gothic Panel Paintings, WKiRDS ASP, Kraków, Poland, 2010.

[15] A. Deneckere, M. Leeflang, M. Bloem et al., "The use of mobile Raman spectroscopy to compare three full-page miniatures from the breviary of Arnold of Egmond," Spectrochimica Acta A, vol. 83, no. 1, pp. 194-199, 2011.

[16] K. Higgitt, M. Spring, and D. Saunders, Pigment-Medium Interactions in Oil Paint Films Containing Red Lead or Lead-TinYellow, vol. 24, National Gallery Technical Bulletin, 2003.

[17] J. Tylicki, The Netherlands Origin of the van den Blocke Family, vol. 71, Biuletyn Historii Sztuki, 2009.

[18] J. Pałubicki, Gdańsk Painters. Painters, Glaziers, Graphic Artists, and Engravers in Modern Gdańsk Archival Materials, vol. 2, The National Museum in Gdańsk, Gdańsk, Poland, 2009.

[19] T. Grzybkowska, Aurea Porta of the Republic of Poland, vol. 2, The National Museum in Gdańsk, Gdańsk, Poland, 1997.

[20] P. Vandenabeele, B. Wehling, L. Moens, H. Edwards, M. de Reu, and G. van Hooydonk, "Analysis with micro-Raman spectroscopy of natural organic binding media and varnishes used in art," Analytica Chimica Acta, vol. 407, no. 1-2, pp. 261274, 2000.

[21] M. Abdel-Ghani, H. G. M. Edwards, B. Stern, and R. Janaway, "Characterization of paint and varnish on a medieval CopticByzantine icon: novel usage of dammar resin," Spectrochimica Acta A, vol. 73, no. 3, pp. 566-575, 2009.

[22] P. Vandenabeele, M. Ortega-Avilès, D. T. Castilleros, and L. Moens, "Raman spectroscopic analysis of Mexican natural artists' materials," Spectrochimica Acta A, vol. 68, no. 4, pp. 10851088, 2007.

[23] C. Daher, C. Paris, A.-S. le Hô, L. Bellot-Gurlet, and J.-P. Échard, "A joint use of Raman and infrared spectroscopies for the identification ofnatural organic media used in ancient varnishes," Journal of Raman Spectroscopy, vol. 41, no. 11, pp. 1494-1499, 2010.

[24] L. Burgio and R. J. H. Clark, "Library of FT-Raman spectra of pigments, minerals, pigment media and varnishes, and supplement to existing library of Raman spectra of pigments with visible excitation," Spectrochimica Acta A, vol. 57, no. 7, pp. 1491-1521, 2001.

[25] I. M. Bell, R. J. H. Clark, and P. J. Gibbs, "Raman spectroscopic library of natural and synthetic pigments (pre- 1850 AD)," Spectrochimica Acta A, vol. 53, no. 12, pp. 2159-2179, 1997.

[26] A. Nevin, I. Osticioli, D. Anglos, A. Burnstock, S. Cather, and E. Castellucci, "Raman spectra of proteinaceous materials used in paintings: a multivariate analytical approach for classification and identification," Analytical Chemistry, vol. 79, no. 16, pp. 6143-6151, 2007.

[27] T. R. Ravindran, A. K. Arora, S. Ramya, R. V. Subba Rao, and B. Raj, "Raman spectroscopic study of medieval Indian art of 17th century," Journal of Raman Spectroscopy, vol. 42, no. 4, pp. 803-807, 2011.

[28] A. Nevin, D. Comelli, I. Osticioli et al., "Multi-photon excitation fluorescence and third-harmonic generation microscopy measurements combined with confocal Raman microscopy for the analysis of layered samples of varnished oil films," Applied Physics A, vol. 100, no. 3, pp. 599-606, 2010.

[29] P. Vandenabeele, F. Verpoort, and L. Moens, "Non-destructive analysis of paintings using fourier transform Raman spectroscopy with fibre optics," Journal of Raman Spectroscopy, vol. 32, no. 4, pp. 263-269, 2001. 
[30] K. Castro, M. Pérez-Alonso, M. D. Rodríguez-Laso, L. A. Fernández, and J. M. Madariaga, "On-line FT-Raman and dispersive Raman spectra database of artists' materials (eVISART database)," Analytical and Bioanalytical Chemistry, vol. 382, pp. 248-285, 2005.

[31] V. S. F. Muralha, L. Burgio, and R. J. H. Clark, "Raman spectroscopy analysis of pigments on 16-17th c. Persian manuscripts," Spectrochimica Acta A, vol. 92, pp. 21-28, 2012.

[32] A. Deneckere, F.-P. Hocquet, A. Born et al., "Direct analysis of the central panel of the so-called Wyts triptych after Jan van Eyck," Journal of Raman Spectroscopy, vol. 41, no. 11, pp. 15001509, 2010.

[33] J. Zuo, X. Zhao, R. Wu, G. Du, C. Xu, and C. Wang, "Analysis of the pigments on painted pottery figurines from the Han Dynasty's Yangling Tombs by Raman microscopy," Journal of Raman Spectroscopy, vol. 34, no. 2, pp. 121-125, 2003.

[34] M. Hanesch, "Raman spectroscopy of iron oxides and (oxy)hydroxides at low laser power and possible applications in environmental magnetic studies," Geophysical Journal International, vol. 177, no. 3, pp. 941-948, 2009.

[35] C. Pelosi, G. Agresti, U. Santamaria, and E. Mattei, "Artifical yellow pigments: production and characterization through spectroscopic methods of analysis," E-Preservation Science, vol. 7, pp. 108-115, 2010.

[36] R. J. H. Clark, L. Cridland, B. M. Kariuki, K. D. M. Harris, and R. Withnall, "Synthesis, structural characterisation and Raman spectroscopy of the inorganic pigments lead tin yellow types I and II and lead antimonate yellow: their identification on medieval paintings and manuscripts," Journal of the Chemical Society, no. 16, pp. 2577-2582, 1995.

[37] I. Borgia, B. G. Brunetti, C. Miliani, C. Ricci, C. Seccaroni, and A. Sgamellotti, "The combined use of lead-tin yellow type I and II on a canvas painting by Pietro Perugino," Journal of Cultural Heritage, vol. 8, no. 1, pp. 65-68, 2007.

[38] C. Sandalinas and S. Ruiz-Moreno, "Lead-tin-antimony yellow: historical manufacture, molecular characterization and identification in seventeenth-century Italian painting," Studies in Conservation, vol. 49, no. 1, pp. 41-52, 2004.

[39] H. G. M. Edwards, D. W. Farwell, E. M. Newton, F. R. Perez, and S. J. Villar, "Raman spectroscopic studies of a 13th century polychrome statue: identification of a "forgotten" pigment," Journal of Raman Spectroscopy, vol. 31, no. 5, pp. 407-413, 2000.

[40] R. J. Meilunas, J. G. Bentsen, and A. Steinberg, "Analysis of aged paint binders by FTIR spectroscopy," Studies in Conservation, vol. 35, pp. 33-51, 1990. 

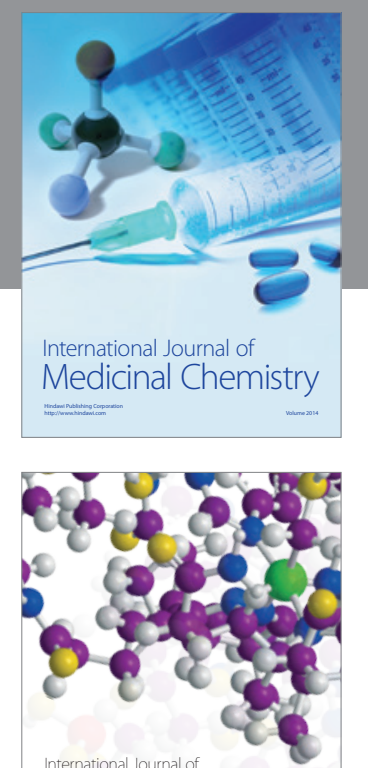

\section{Carbohydrate} Chemistry

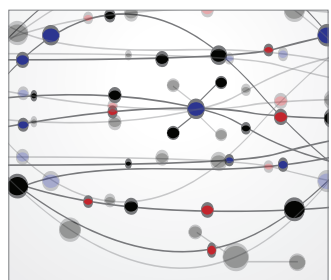

The Scientific World Journal
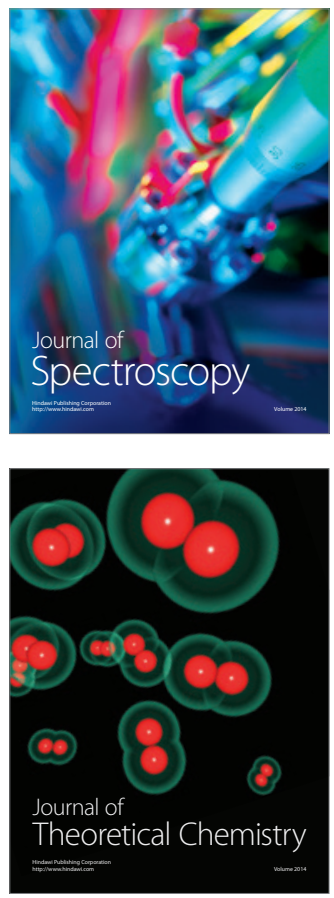
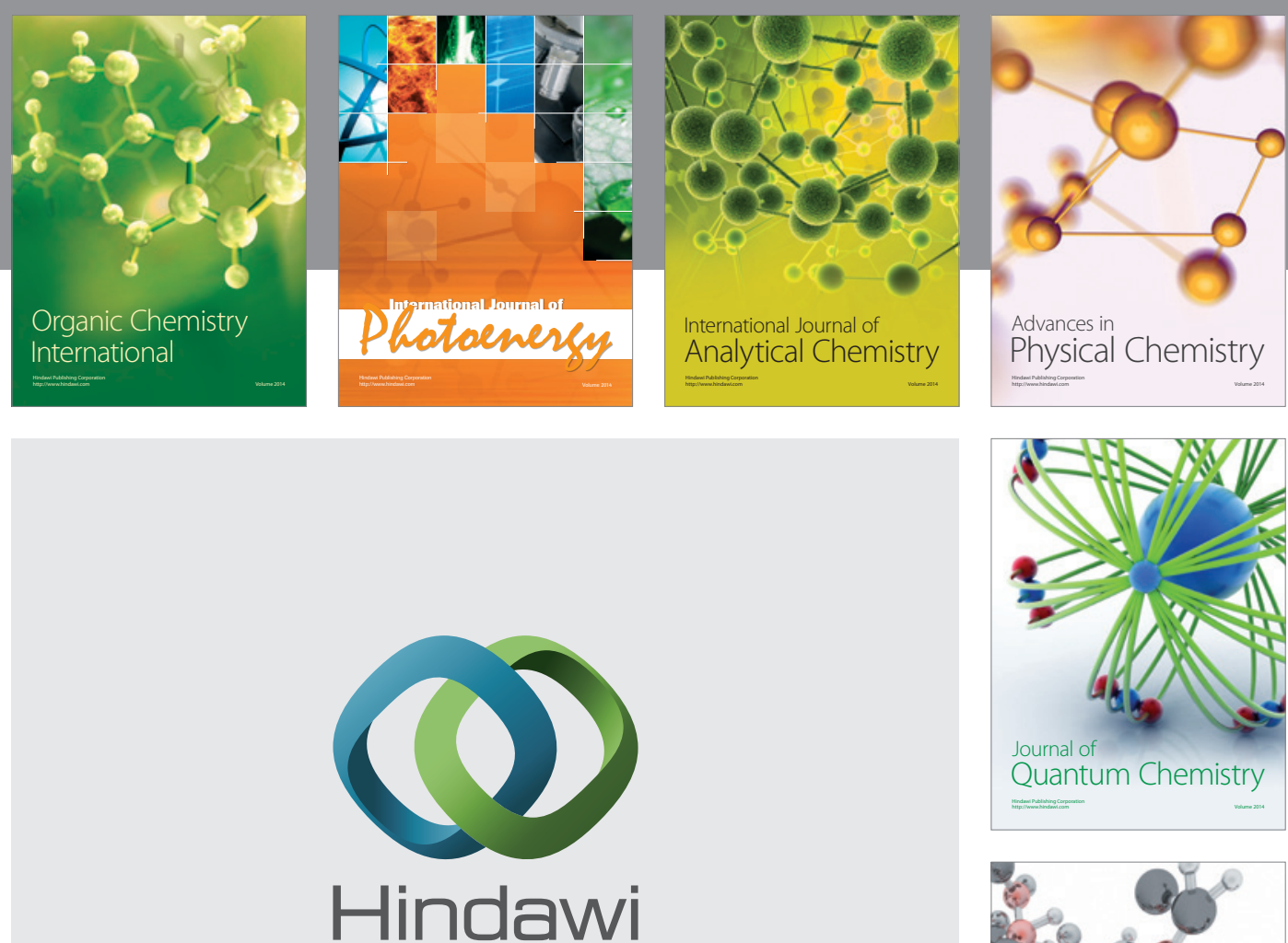

Submit your manuscripts at

http://www.hindawi.com

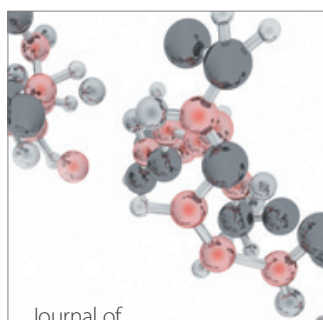

Analytical Methods

in Chemistry

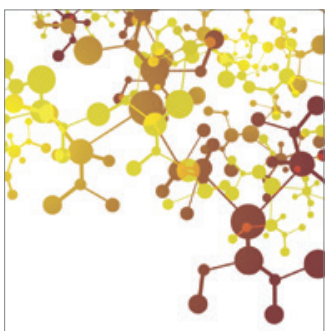

Journal of

Applied Chemistry

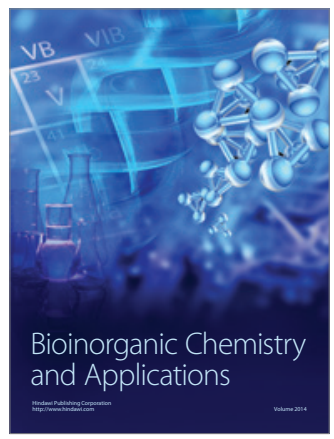

Inorganic Chemistry
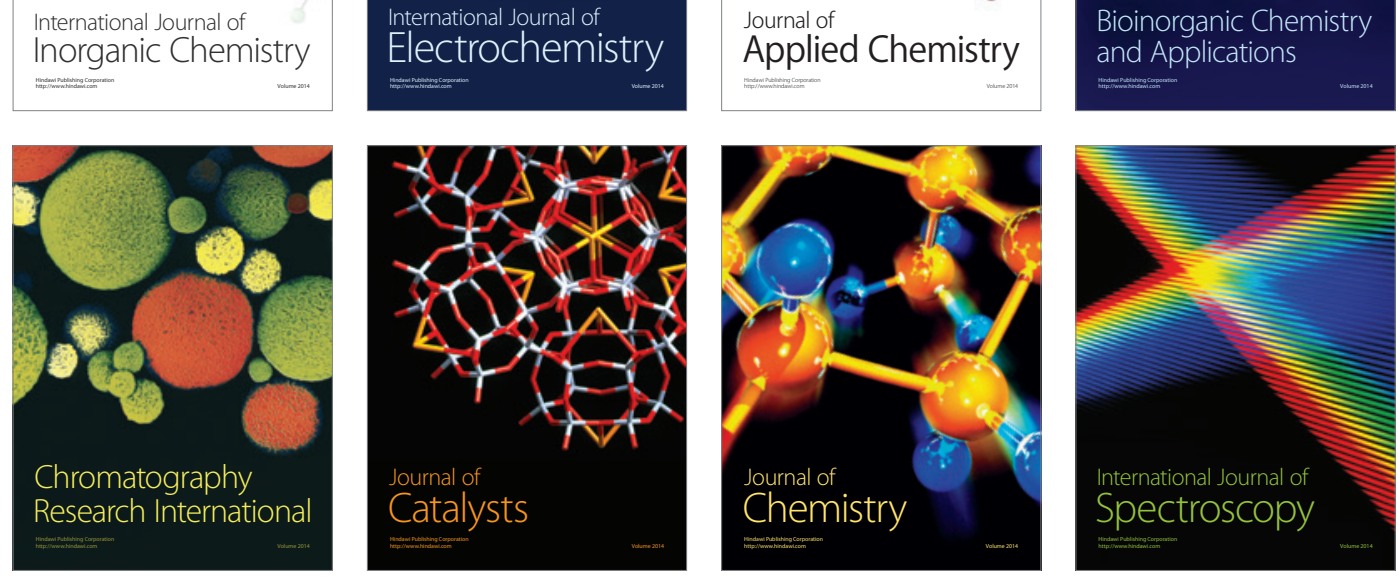